Article

\title{
Survivability of Anhydrobiotic Cyanobacteria in Salty Ice: Implications for the Habitability of Icy Worlds
}

\author{
Barbara Cosciotti ${ }^{1}\left(\mathbb{D}\right.$, Amedeo Balbi $^{2}{ }^{\circledR}$, Alessandra Ceccarelli ${ }^{1}\left(\mathbb{D}\right.$, Claudia Fagliarone $^{3}$,

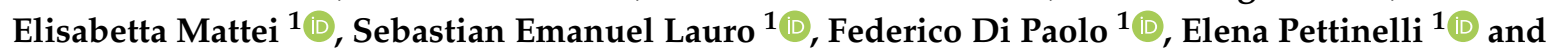 \\ Daniela Billi ${ }^{3, *}$ \\ 1 Department of Mathematics and Physics, University of Rome Tre, 00154 Rome, Italy; \\ cosciotti@fis.uniroma3.it (B.C.); ceccarelli.ap@gmail.com (A.C.); mattei@fis.uniroma3.it (E.M.); \\ lauro@fis.uniroma3.it (S.E.L.); dipaolo@fis.uniroma3.it (F.D.P.); pettinelli@fis.uniroma3.it (E.P.) \\ Department of Physics, University of Rome Tor Vergata, 00133 Rome, Italy; amedeo.balbi@roma2.infn.it \\ Department of Biology, University of Rome Tor Vergata, 00133 Rome, Italy; claudia.fagliarone@hotmail.it \\ * Correspondence: billi@uniroma2.it
}

Received: 5 October 2019; Accepted: 19 November 2019; Published: 22 November 2019

Abstract: Two anhydrobiotic strains of the cyanobacterium Chroococcidiopsis, namely CCMEE 029 and CCMEE 171, isolated from the Negev Desert in Israel and from the Dry Valleys in Antarctica, were exposed to salty-ice simulations. The aim of the experiment was to investigate the cyanobacterial capability to survive under sub-freezing temperatures in samples simulating the environment of icy worlds. The two strains were mixed with liquid solutions having sub-eutectic concentration of $\mathrm{Na}_{2} \mathrm{SO}_{4}, \mathrm{MgSO}_{4}$ and $\mathrm{NaCl}$, then frozen down to different final temperatures $(258 \mathrm{~K}, 233 \mathrm{~K}$ and $203 \mathrm{~K})$ in various experimental runs. Both strains survived the exposure to $258 \mathrm{~K}$ in $\mathrm{NaCl}$ solution, probably as they migrated in the liquid veins between ice grain boundaries. However, they also survived at $258 \mathrm{~K}$ in $\mathrm{Na}_{2} \mathrm{SO}_{4}$ and $\mathrm{MgSO}_{4}$-salty-ice samples-that is, a temperature well below the eutectic temperature of the solutions, where liquid veins should not exist anymore. Moreover, both strains survived the exposure at $233 \mathrm{~K}$ in each salty-ice sample, with CCMEE 171 showing an enhanced survivability, whereas there were no survivors at $203 \mathrm{~K}$. The survival limit at low temperature was further extended when both strains were exposed to $193 \mathrm{~K}$ as air-dried cells. The results suggest that vitrification might be a strategy for microbial life forms to survive in potentially habitable icy moons, for example in Europa's icy crust. By entering a dried, frozen state, they could be transported from niches, which became non-habitable to new habitable ones, and possibly return to metabolic activity.

Keywords: vitrification; desert cyanobacteria; laboratory simulations; habitability; Europa; icy moons; liquid veins; ice crystals

\section{Introduction}

Potentially habitable worlds are usually defined in terms of three basic requirements: the presence of liquid water, the availability of biogenic elements and a free energy source [1]. In our solar system, two icy worlds are currently attracting significant attention as environments which may meet all such criteria: Enceladus and Europa, moons of Saturn and Jupiter, respectively [2]. There is strong evidence that both moons have a large reservoir of liquid water below the icy crust, and that hydrothermal activity may take place on the ocean floor [3,4]. Hypothetical life-forms could be transported from the subsurface ocean with the water plumes [5] and deposited on or near the icy surface. Within the ice shell additional habitats might be present, resembling veins at grain boundaries and brine zones as reported for glaciers and ice sheets on Earth [3,4], albeit subsurface melt pockets due to tidal convection 
or eutectic melting [6]. Energy for metabolic processes could be provided on the seafloor by tidal activity, radiogenic heating and serpentinization [7].

Europa and Enceladus are astrobiologically relevant not only because they are potentially among the most interesting targets in the Solar System for finding life, but also because they can serve as candidates for a case study of icy planetary environments, that may be quite common in the universe and support life even outside the circumstellar habitable zone [8-10]. It is therefore crucial to complement the in situ and remote study of these icy moons with laboratory simulations in order to assess their habitability.

Cold-adapted microbes thrive in environments considered as analogues of potentially habitable icy worlds [11], where they occur in three microhabitats: (i) within briny veins at the triple grain-boundaries in polycrystalline ice [12,13]; (ii) associated with mineral grains in permafrost in thin films of unfrozen water [14]; and (iii) inside ice crystals [15].

In liquid veins, microbes need to cope with increased solute concentrations and have access to water and energy; however, when they are encased in solid ice, the limiting factor to their metabolism is nutrient diffusion through a solid, which is orders of magnitude slower than through a liquid [12]. Survival clearly depends on various physical-chemical features and cold-adaptation strategies. Ice-inhabitants accumulate compatible solutes to prevent osmotic shock, and synthetize ice-binding or anti-freeze proteins (localized on their cell surface or secreted outside) to prevent ice-crystal formation and cellular damage; they also release exopolymeric substances that may function as anti-freeze agents [16].

A key question is whether microbes simply survive by being trapped frozen in glacial ice, or if they are metabolically active, thus repairing macromolecular damage and even dividing and completing their life cycle. Despite the relevance of the issue, there is no generally accepted value for the lower temperature limit for life on Earth. Microbial metabolism has been reported, albeit with slow rates, occurring at temperatures in the range from $256 \mathrm{~K}$ to $253 \mathrm{~K}$ [17]. Indeed, evidence suggests that, during cooling in the presence of external ice, microbes will undergo freeze-induced desiccation and glass transition (vitrification). Thus vitrified, dormant cells are able to survive at very low temperatures [17]. Indeed, by extrapolating metabolic data at subzero temperatures, the threshold for microbial metabolism was set at $233 \mathrm{~K}$ [18].

The presence of salts, which lower the freezing point of the solution down to the eutectic temperature (or even lower if in metastable state), might expand the temperature range for potentially habitable extra-terrestrial environments. In polycrystalline ice, the existence of liquid veins depends on the ice temperature and on the eutectic temperature of the system (i.e. the temperature at which the solution precipitates as a mixture of solid salt and ice). In a binary system, according to equilibrium thermodynamics, the veins are liquid when the ice temperature is above the eutectic temperature of the system, whereas an immiscible solid mixture of ice and salt crystals freezes below such temperature (see $[19,20]$ for details). In natural terrestrial ice many chemical species are present together, thus the existence and predominance of a microenvironment over the other (i.e. liquid veins or solid grains) depends on the type of chemical impurities and the temperature of the ice.

On Europa's surface, the presence of magnesium sulfate, sodium sulfate and sodium carbonate (and, potentially, of sulfuric acid) has been revealed by Galileo Near-Infrared Mapping Spectrometer [21]. Recently, the additional presence of sodium chloride was suggested by spectral analysis made with the Hubble Space Telescope [22]. On Earth, sodium chloride is the most common salt found in high-salt environments, although calcium chloride, sodium and magnesium sulfates have been reported in Don Juan Pond, Antarctica [23] and Spotted Lake, Canada [24], respectively.

The investigation of microbial survival in different solutes under freezing conditions is relevant to better define life-limiting factors and to evaluate the possibility of non-Earth icy environments being habitable [11]. Very little is known on the behavior of microbes in salt solutions under non-Earth conditions. For instance, bacteria have been reported to be viable and metabolically active in a type of ice not found on Earth, the so-called ice-VI, produced under high pressure conditions, and in 
which the solid phase of water, differently for the Earthly ice-Ih, is heavier than the liquid phase [25]. Hence laboratory icy-moon simulations might help to obtain new insights into bacterial endurance in extra-terrestrial cold environments.

Here we sought to address the hypothesis that cyanobacteria from hot and cold deserts $[26,27]$ remain viable after vitrifying upon exposure to different salt solutions at subfreezing temperatures. Indeed, the desiccation resistance of these non-akinete forming cyanobacteria depends on their ability to enter upon air-drying, an ametabolic state and recover their metabolism when water becomes available, a phenomenon known as anhydrobiosis [26,27]. Hence, we selected Chroococcidiopsis sp. CCMEE 171 isolated from endolithic communities in the McMurdo Dry Valleys in Antarctica, considered the coldest and driest place on Earth, where endoliths are metabolically active at $253 \mathrm{~K}$ [28] and persist in a dried-frozen state for most of the year [29]. On the other hand, Chroococcidiopsis sp. CCMEE 029 isolated from the Negev Desert, Israel, was selected due to its capability of surviving, when dried, temperatures as low as $248 \mathrm{~K}$, under laboratory conditions [30].

In the present work, these two anhydrobiotic cyanobacteria were exposed to water solutions progressively cooled down to temperatures much lower than their eutectic temperatures. Since the salt concentration in icy moon crusts is unknown, a typical impurity load found in terrestrial glacial ice was used as a reference [12]. Thus, sub-eutectic solutions $\left(10^{-4} \mathrm{M}\right)$ of $\mathrm{Na}_{2} \mathrm{SO}_{4}, \mathrm{MgSO}_{4}$ and $\mathrm{NaCl}$ were prepared, and each solution was frozen down to three final temperatures, namely $258 \mathrm{~K}, 233 \mathrm{~K}$ and $203 \mathrm{~K}$, in different laboratory simulations. After exposure, survival was evaluated by monitoring the growth capability after transfer to standard growth medium and incubation under routine conditions.

\section{Materials and Methods}

\subsection{Cyanobacterial Strains and Culture Conditions}

The strains used in our study are part of the Culture Collection of Microorganisms from Extreme Environments (CCMEE), maintained at the Department of Biology, University of Rome Tor Vergata. Hereafter, they are indicated as CCMEE 029 and CCMEE 171. Chroococcidiopsis sp. CCMEE 029 (N6904) and Chroococcidiopsis sp. CCMEE 171 (A789-2) were isolated by E. Imre Friedmann and Roseli Ocampo-Friedmann from cryptoendolithic growth in sandstones in Makhtesh Ramon, Negev desert (Israel) and in the University Valley, McMurdo Dry Valleys (Antarctica), respectively. For strain CCMEE 171 the growth optimum temperature is about $25^{\circ} \mathrm{C}$ (unpublished), as reported for CCMEE 134, isolated from Beacon Valley in Antarctica [31]. The two strains are not axenic but routine transfer on agarized BG-11 medium [32] reduced the bacterial contamination to about $0.0001 \%$. Cyanobacteria were grown under routine conditions at $25^{\circ} \mathrm{C}$ in liquid BG-11 medium under a photon flux density of $40 \mu \mathrm{mol} / \mathrm{m}^{2} / \mathrm{s}$ provided by fluorescent cool-white bulbs under continuous light illumination. For the simulations reported below, cultures in the exponential growth phase $\left(0.1-1 \times 10^{7}\right.$ cells $\left./ \mathrm{ml}\right)$ were used.

\subsection{Salty-Ice Environments}

Icy samples were made, following [12], by preparing $10^{-4} \mathrm{M}$ salt binary solutions, in ultrapure and sterile water $\left(\mathrm{ddH}_{2} \mathrm{O}\right)$, with $\mathrm{MgSO}_{4}, \mathrm{Na}_{2} \mathrm{SO}_{4}$ and $\mathrm{NaCl}$ as solute. For each salt solution three different simulations were performed at $258 \mathrm{~K}, 233 \mathrm{~K}$ and $203 \mathrm{~K}$, by using a climatic chamber capable of reaching $198 \mathrm{~K}$ (Angelantoni DY340C, see Figure 2e,f in [33]). The temperature was measured by two Pt100 sensors, one located close to the sample and the other inside the chamber. The climatic chamber is hosted at the Mathematics and Physics Department of Roma Tre University and was designed and built to study different ice physical properties, as a support to the RIME experiment on board the JUICE 2022 ESA mission. It allows to control both temperature and humidity, and to generate temperature gradients as fast as $2 \mathrm{~K} / \mathrm{min}$, in cooling mode, and $4 \mathrm{~K} / \mathrm{min}$, in heating mode. In each experimental run the cooling time was different, about $20 \mathrm{~min}, 33 \mathrm{~min}$ and $48 \mathrm{~min}$, at $258 \mathrm{~K}, 233 \mathrm{~K}$ and $203 \mathrm{~K}$, as shown in Figure 1. For each experimental run, once reached the lowest value the sample was maintained at such temperature for $2 \mathrm{~h}$. 

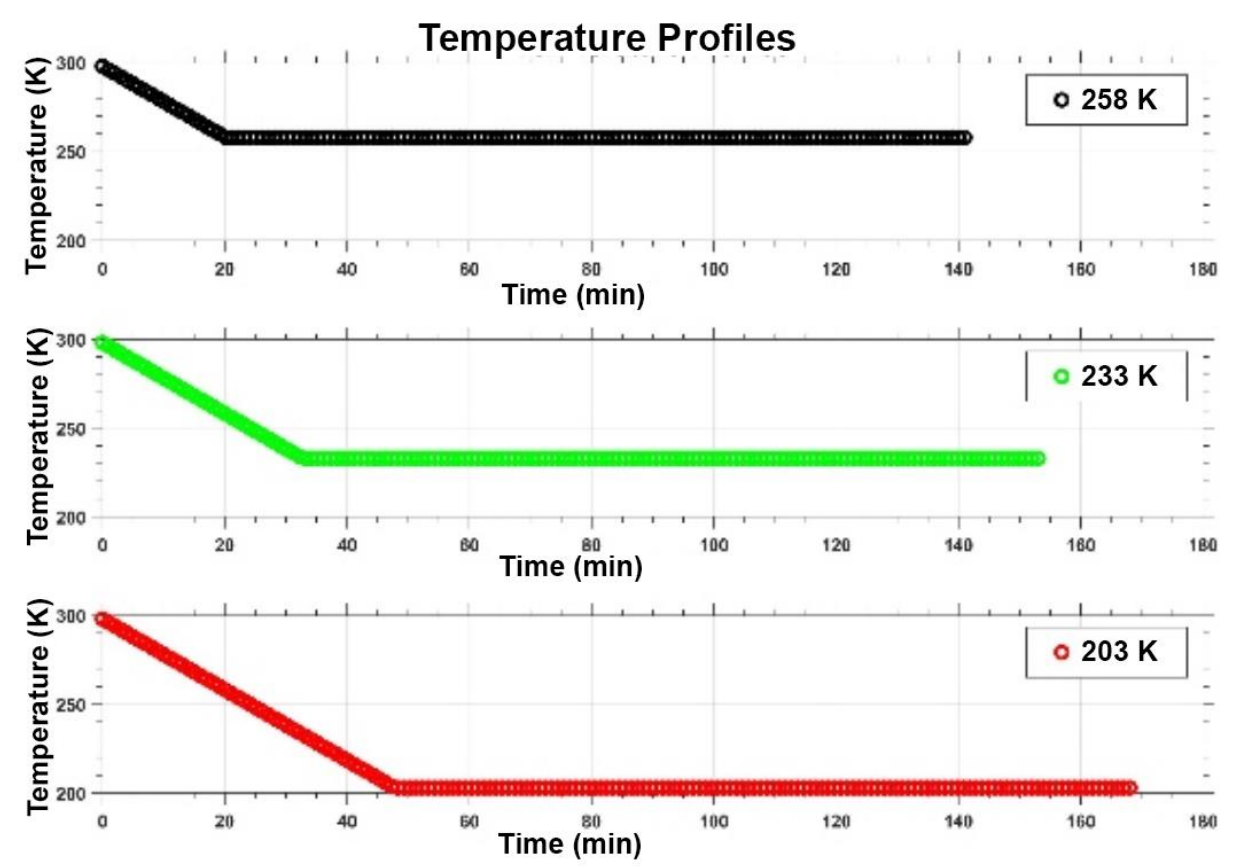

Figure 1. Temperature trend for the three experiments.

\subsection{Exposure of Cyanobacteria to Salty-Icy Environments}

Cyanobacteria were resuspended in $10^{-4} \mathrm{M}$ solutions of $\mathrm{MgSO}_{4}, \mathrm{Na}_{2} \mathrm{SO}_{4}$ or $\mathrm{NaCl}$ according to [12] and exposed to the cooling procedure described above. Samples were prepared as follows: 1-mL culture aliquots were pelleted by centrifugation at $5000 \mathrm{~g}$ for $10 \mathrm{~min}$, resuspended in $5 \mathrm{~mL}$ of each salt solution or in $5 \mathrm{~mL}$ of ddH $\mathrm{H}_{2} \mathrm{O}$, and transferred in $25 \mathrm{~cm}^{2}$ culture flasks. Controls were prepared from 1-mL culture aliquots resuspended in $5 \mathrm{~mL}$ of BG-11 medium and maintained at room temperature (RT). After each simulation, the icy samples were allowed to thaw at RT for about $2 \mathrm{~h}$, washed with BG-11 medium, resuspended in $5 \mathrm{~mL}$ of BG-11 medium and incubated under routine culture conditions.

\subsection{Evaluation of the Effects of Salt Solutions and Ddh ${ }_{2} \mathrm{O}$ on Cell Viability}

Cyanobacterial viability after incubation in salt solutions and in $\mathrm{ddH}_{2} \mathrm{O}$ at $\mathrm{RT}$ was evaluated as follows: 1-mL culture aliquots were resuspended in $5 \mathrm{~mL}$ of $10^{-4} \mathrm{M}$ solutions of $\mathrm{MgSO}_{4}, \mathrm{Na}_{2} \mathrm{SO}_{4}$ and $\mathrm{NaCl}$ or $\mathrm{ddH}_{2} \mathrm{O}$ as described above, and incubated at RT for $4 \mathrm{~h}$ (in parallel to salty-ice simulation experiments). Then cells were washed with BG-11 medium, resuspended in $5 \mathrm{~mL}$ of BG-11 medium, transferred in $25 \mathrm{~mL}$ culture flasks and incubated under routine culture conditions.

\subsection{Exposure of Air-Dried Cyanobacteria to $233 \mathrm{~K}$ and $193 \mathrm{~K}$}

Air-dried cyanobacteria were obtained from 1-mL culture aliquots by centrifugation at $5000 \mathrm{~g}$ for $10 \mathrm{~min}$ and dried overnight under a sterile air stream. Dried pellets were exposed as follows: (i) at $233 \mathrm{~K}$ for $2 \mathrm{~h}$ by using the climatic chamber; (ii) $193 \mathrm{~K}$ for $72 \mathrm{~h}$ by using a laboratory refrigerator. Frozen samples were allowed to thaw at RT for about $2 \mathrm{~h}$, resuspended in $5 \mathrm{~mL}$ of BG-11 medium in $25 \mathrm{~cm}^{2}$ culture flasks, and incubated under routine conditions. Controls were prepared by air-drying 1-mL culture aliquots as reported above, and by resuspending the air-dried pellets in $5 \mathrm{~mL}$ of BG-11 medium at the same time of the frozen samples.

\subsection{Cell Viability}

The growth rate of each exposed sample and control transferred in $5 \mathrm{~mL}$ of BG-11 medium under routine culture conditions, was monitored for 3 weeks by performing optical density measurements at $730 \mathrm{~nm}$. Values are reported as means, based on two independent simulations with three replicates. 


\section{Results}

\subsection{Salty-Ice Environments}

The conditions of the different experimental runs are summarized in Table 1. According to thermodynamics models of binary systems, because water and salts are totally miscible in the liquid phase but immiscible in the solid phase, below the eutectic temperature they should form a solid mixture of salt and ice grains. Thus, as in this study the salt solutions are quite diluted $\left(10^{-4} \mathrm{~mol} / \mathrm{L}\right)$, it is expected that far below the eutectic temperature the mixture is essentially composed by a matrix of polycrystalline ice with grains having an eutectic composition. Such grains are made of pure ice and pure salt crystals finely dispersed or distributed in alternate layers [19]. Thus, during cooling, the ice crystals segregate as a solid phase whereas the liquid phase becomes progressively more concentrated in salts. Once reached the eutectic temperature the salt solution starts to freeze. Table 1 shows that the eutectic temperatures of $\mathrm{MgSO}_{4}$ and $\mathrm{Na}_{2} \mathrm{SO}_{4}$ (i.e., $269.55 \mathrm{~K}$ and $271.99 \mathrm{~K}$, respectively) are well above $258 \mathrm{~K}$, while the eutectic temperature of $\mathrm{NaCl}(252.06 \mathrm{~K})$ is lower than $258 \mathrm{~K}$. Thus, it is expected that at $258 \mathrm{~K}$ the salty solutions containing $\mathrm{MgSO}_{4}$ and $\mathrm{Na}_{2} \mathrm{SO}_{4}$ are totally frozen, whereas the $\mathrm{NaCl}$ sample is only partially frozen, as it should contain a non-negligible quantity of salty liquid solution (probably in veins) having a concentration close to that of the eutectic composition (see Table 1). Conversely, because the other cooling experiments reached much lower final temperatures (233 K and $203 \mathrm{~K}$ ), which are well below the eutectic temperatures of the three salt solutions (see Table 1), it is expected that no liquid salt solution would be left inside the icy sample. Therefore, at such low temperatures the samples should be made of a mixture of polycrystalline ice (the dominant phase) and disseminated grans of pure salt and icy crystals (frozen eutectic).

Table 1. Experimental conditions and eutectic properties of the salty-ice samples used in this study.

\begin{tabular}{|c|c|c|c|c|}
\hline Liquid Solution & $\begin{array}{l}\text { Hydrated Form of } \\
\text { Salt at Eutectic } \\
\text { Concentration }\end{array}$ & $\begin{array}{c}\text { Initial Salt } \\
\text { Concentration } \\
(\mathrm{mol} / \mathrm{L})\end{array}$ & $\begin{array}{c}\text { Eutectic } \\
\text { Temperature/Concentration } \\
(\mathrm{K} / \mathbf{w t} \%)\end{array}$ & $\begin{array}{c}\text { Sample } \\
\text { Temperature (K) }\end{array}$ \\
\hline $\mathrm{NaCl}-\mathrm{H}_{2} \mathrm{O}$ & $\mathrm{NaCl} \cdot 2 \mathrm{H}_{2} \mathrm{O}$ & $10^{-4}$ & $252.35 / 23.3$ & $\begin{array}{l}258 \\
233 \\
203\end{array}$ \\
\hline $\mathrm{Na}_{2} \mathrm{SO}_{4}-\mathrm{H}_{2} \mathrm{O}$ & $\mathrm{Na}_{2} \mathrm{SO}_{4} \cdot 10 \mathrm{H}_{2} \mathrm{O}$ & $10^{-4}$ & $271.99 / 3.8$ & $\begin{array}{l}258 \\
233 \\
203\end{array}$ \\
\hline $\mathrm{MgSO}_{4}-\mathrm{H}_{2} \mathrm{O}$ & $\mathrm{MgSO}_{4} \cdot 11 \mathrm{H}_{2} \mathrm{O}$ & $10^{-4}$ & 269.55/17.55 & $\begin{array}{l}258 \\
233 \\
203\end{array}$ \\
\hline $\mathrm{ddH}_{2} \mathrm{O}$ & Pure ice & - & - & $\begin{array}{l}258 \\
233 \\
203\end{array}$ \\
\hline
\end{tabular}

\subsection{Cold And Hot Desert Strains Survived in Salty-Icy Conditions at $258 \mathrm{~K}$}

After the exposure for $2 \mathrm{~h}$ at $258 \mathrm{~K}$ in icy samples containing $\mathrm{NaCl}, \mathrm{Na}_{2} \mathrm{SO}_{4}$ or $\mathrm{MgSO}_{4}$, cells of strains CCMEE 171 and CCMEE 029 were transferred to liquid BG-11 medium under routine growth conditions. Strain CCMEE 171 survived in the three frozen salt solutions, as shown by their growth recovery (Figure 2A). However, after 21 days of growth, cell densities were lower than that of control, i.e., cells maintained in BG-11 medium under routine culture conditions (Figure 2A). By contrast, strain CCMEE 029 showed a growth recovery comparable to control after exposure to sub-freezing temperature in $\mathrm{MgSO}_{4}-\mathrm{H}_{2} \mathrm{O}$ solution (Figure 2B); while a reduced growth occurred after exposure in the other salt solutions (Figure 2B). For both strains there were no survivors after exposure to $258 \mathrm{~K}$ in $\mathrm{ddH}_{2} \mathrm{O}$ (Figure 2A,B). 

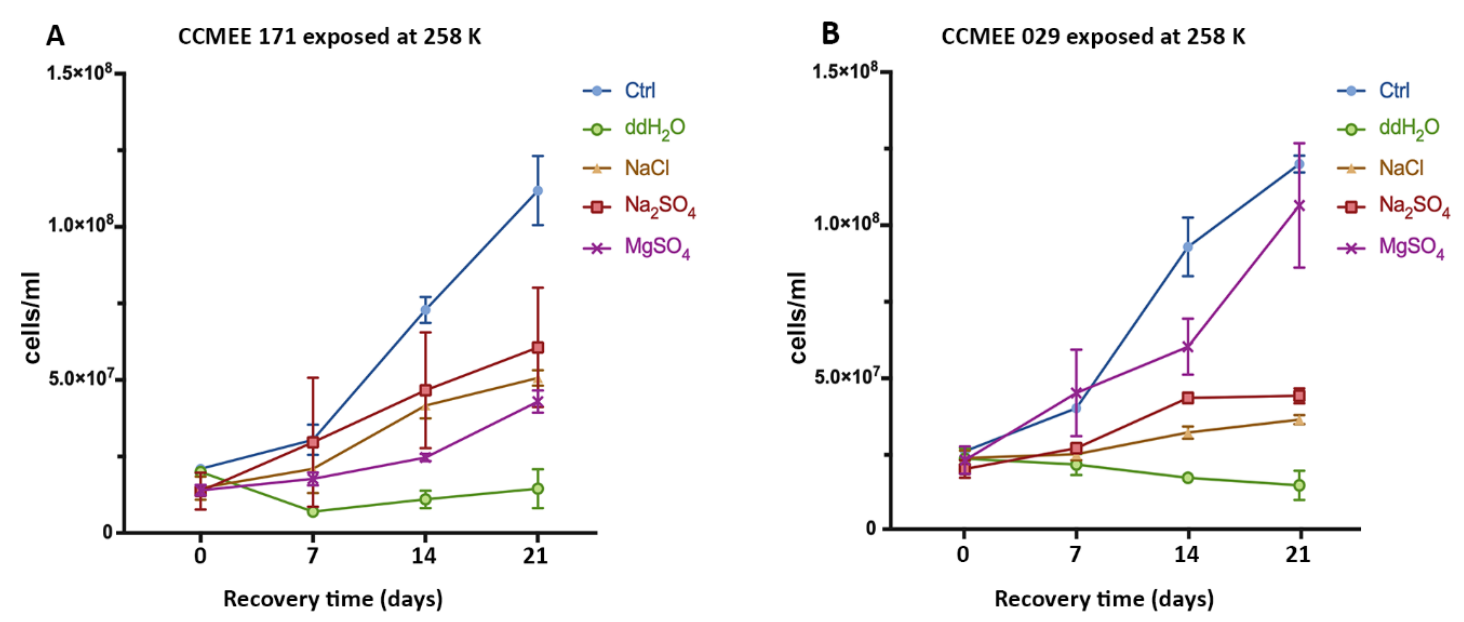

Figure 2. Growth curves of Chroococcidiopsis strains CCMEE 171 (A) and CCMEE 029 (B) transferred to liquid BG-11 medium under routine culture conditions after exposure to $258 \mathrm{~K}$ in icy samples containing $\mathrm{NaCl}, \mathrm{Na}_{2} \mathrm{SO}_{4}$ or $\mathrm{MgSO}_{4}$. Ctrl: Control cells maintained in liquid BG-11 medium at RT during the simulation.

\subsection{Enhanced Surival of the Cold Desert Strain in Salty-Icy Conditions at $233 \mathrm{~K}$}

In the experiment where strain CCMEE 171 was exposed to $233 \mathrm{~K}$ for $2 \mathrm{~h}$, growth recovery occurred after transfer to liquid BG-11 medium under routine culture conditions (Figure 3A), regardless of the salt solution $\left(\mathrm{NaCl}, \mathrm{Na}_{2} \mathrm{SO}_{4}\right.$ or $\left.\mathrm{MgSO}_{4}\right)$. However, after 21 days of growth, cell samples exposed to sub-frozen solutions of $\mathrm{NaCl}$ and $\mathrm{Na}_{2} \mathrm{SO}_{4}$, reached cell densities reduced if compared to control (Figure 3A). Conversely, strain CCMEE 029 exposed to $233 \mathrm{~K}$ in each one of the salt solutions showed a delay in the recovery and cell densities were lower than control (Figure 3B). For both strains there were no survivors after exposure to $233 \mathrm{~K}$ in $\mathrm{ddH}_{2} \mathrm{O}$ (Figure $3 \mathrm{~A}, \mathrm{~B}$ ).
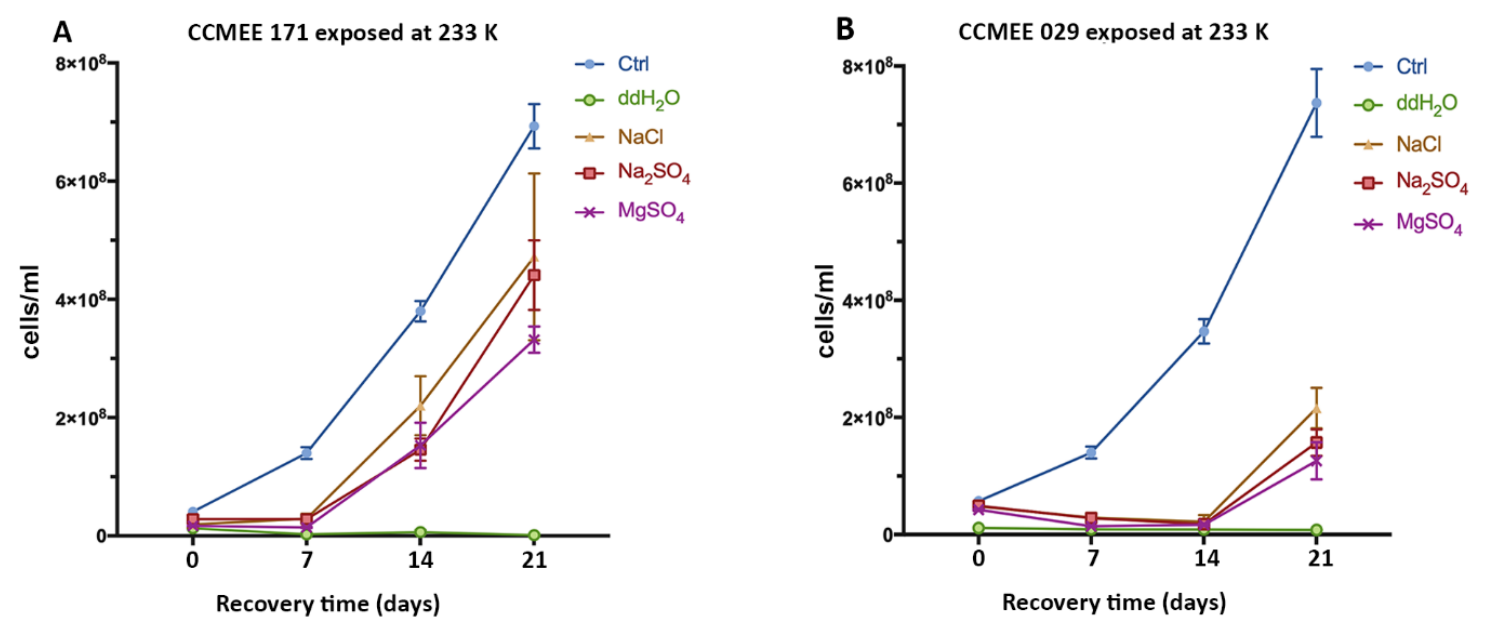

Figure 3. Growth curves of Chroococcidiopsis strains CCMEE 171 (A) and CCMEE 029 (B) transferred to liquid BG-11 medium under routine culture conditions after exposure to $233 \mathrm{~K}$ in icy samples containing $\mathrm{NaCl}, \mathrm{Na}_{2} \mathrm{SO}_{4}$ or $\mathrm{MgSO}_{4}$. Ctrl: Control cells maintained in liquid BG-11 medium at RT during the simulation.

\subsection{Cold and Hot Desert Strains Died in Salty-Icy Conditions at $203 \mathrm{~K}$}

No survivors occurred among cells of strains CCMEE 171 and CCMEE 029 after being exposed for $2 \mathrm{~h}$ to $203 \mathrm{~K}$, regardless of the salt used, because no increase in cell densities was observed after transfer to liquid BG-11 medium under routine culture conditions (Figure 4A,B). 

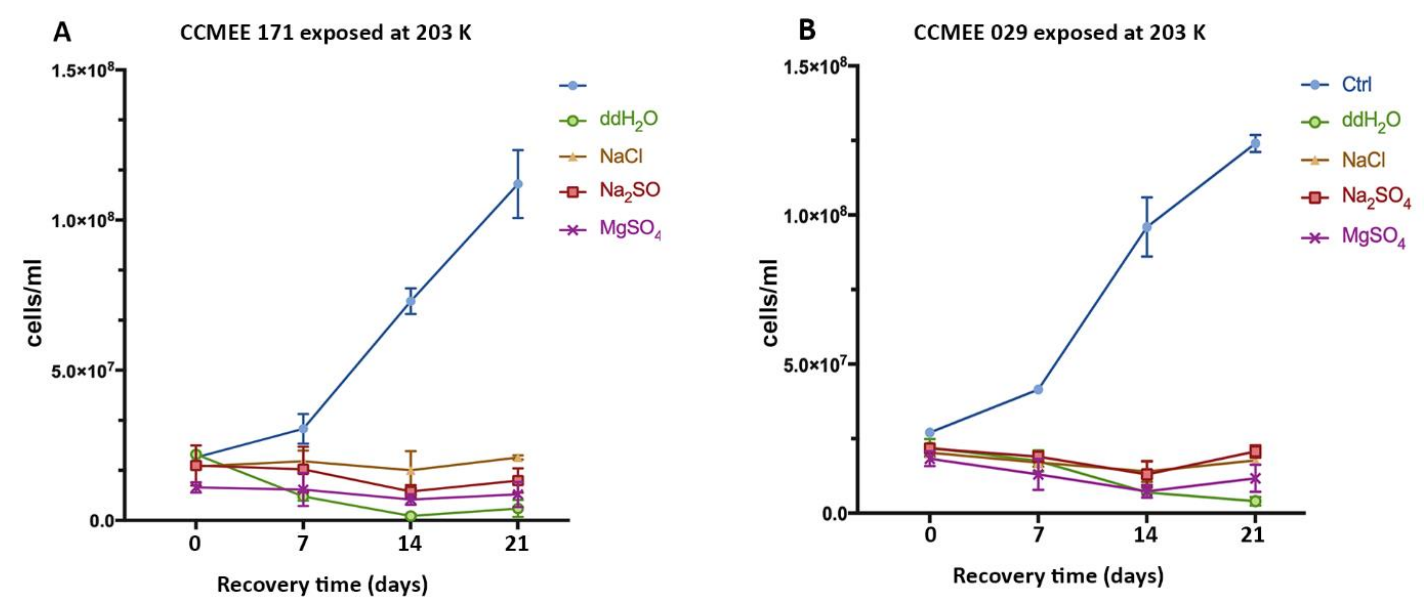

Figure 4. Growth curves of Chroococcidiopsis strains CCMEE 171 (A) and CCMEE 029 (B) transferred to liquid BG-11 medium under routine culture conditions after exposure to $203 \mathrm{~K}$ in icy samples containing $\mathrm{NaCl}, \mathrm{Na}_{2} \mathrm{SO}_{4}$ or $\mathrm{MgSO}_{4}$. Ctrl: Control cells maintained in liquid BG-11 medium at RT during the simulation.

\subsection{Incubation in $d d \mathrm{H}_{2} \mathrm{O}$ and Salt Solutions Reduced Cell Viability}

The incubation of strains CCMEE 171 and CCMEE 029 in $\mathrm{ddH}_{2} \mathrm{O}$ and in $10^{-4} \mathrm{M}$ solutions of $\mathrm{NaCl}$, $\mathrm{Na}_{2} \mathrm{SO}_{4}, \mathrm{MgSO}_{4}$ at $\mathrm{RT}$ for $4 \mathrm{~h}$ (in parallel to salty-ice simulation experiments) reduced cell viability as shown in Figure 4. After 21 days, strain CCMEE 171 showed cell densities reduced by the incubation in $\mathrm{ddH}_{2} \mathrm{O}, \mathrm{NaCl}, \mathrm{Na}_{2} \mathrm{SO}_{4}$, and $\mathrm{MgSO}_{4}$ to $87 \%, 71 \%, 66 \%$ and $70 \%$ of control (i.e. cells maintained in BG-11 medium under routine growth conditions), respectively (Figure 5). While cell densities of strain CCMEE 029 were reduced by the incubation in $\mathrm{ddH}_{2} \mathrm{O}, \mathrm{NaCl}, \mathrm{Na}_{2} \mathrm{SO}_{4}$, and $\mathrm{MgSO}_{4}$ to $98 \%, 77 \% 53 \%$ and $68 \%$ of control (i.e. cells maintained in liquid BG-11 medium), respectively (Figure 5).

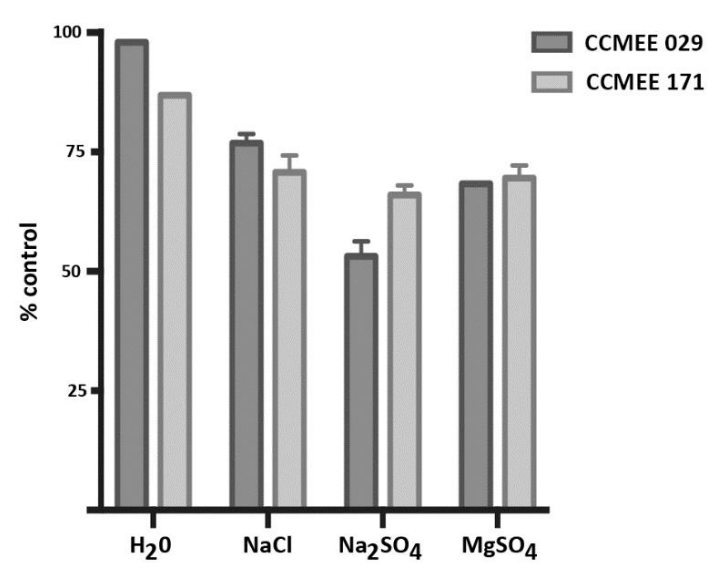

Figure 5. Cell densities of Chroococcidiopsis strains CCMEE 171 and CCMEE 029 incubated in $\mathrm{ddH}_{2} \mathrm{O}$, $\mathrm{NaCl}, \mathrm{Na}_{2} \mathrm{SO}_{4}$ or $\mathrm{MgSO}_{4}$ for $4 \mathrm{~h}$ at RT after incubation for 21 days in liquid BG-11 medium under routine culture conditions. Cell densities are shown as \% of control (cells maintained in liquid BG-11 medium at RT during the treatment).

\subsection{Air-dried Cells of Hot and Cold Desert Strains Survived Sub-Freezing Temperatures}

Air-dried cells of strains CCMEE 171 and CCMEE 029 survived the exposure to $233 \mathrm{~K}$ for $2 \mathrm{~h}$ in all three salt solutions, as shown by the cell densities reached after 21 days of incubation in liquid BG-11 medium under routine culture conditions (Figure 6). The growth rate of strain CCMEE 171 was comparable to that of control (Figure 6A), whereas that of CCMEE 029 was slightly reduced (Figure 6B). When air-dried cells of strains CCMEE 171 and CCMEE 029 were incubated at $193 \mathrm{~K}$ for $72 \mathrm{~h}$ by using 
a laboratory refrigerator and transferred to liquid BG-11 medium under routine culture conditions, after 21 days their cell densities were comparable to control (not shown).
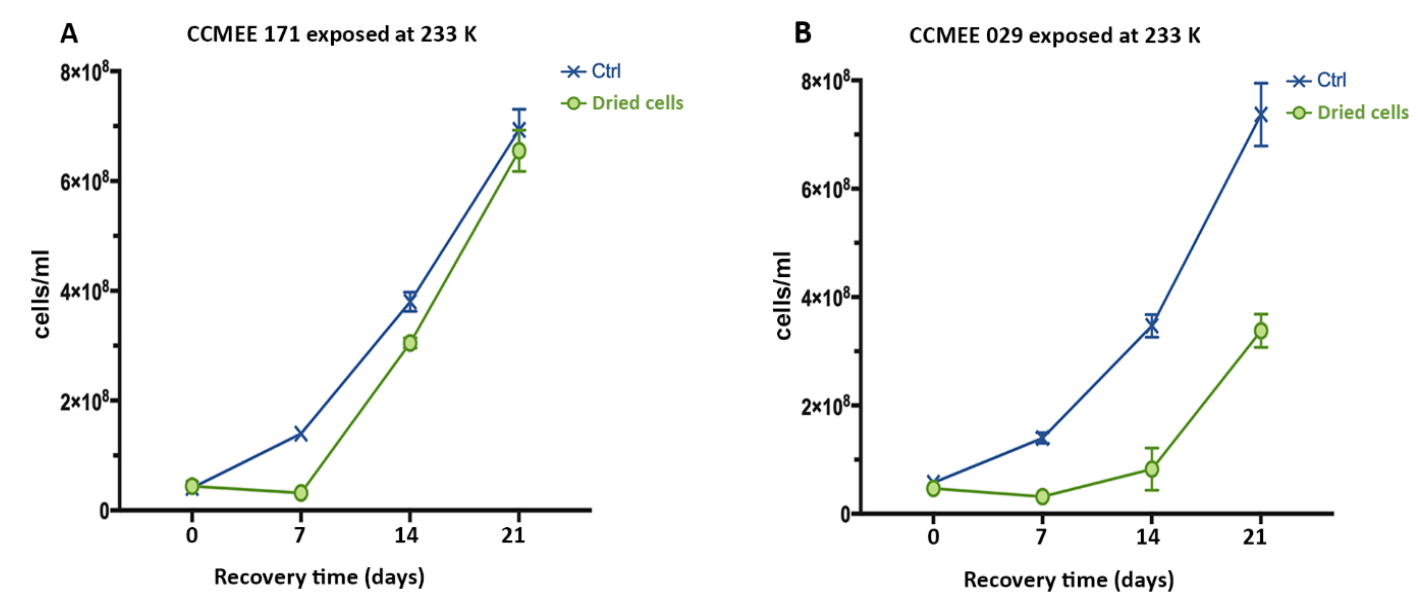

Figure 6. Growth curves of Chroococcidiopsis strains CCMEE 171 (A) and CCMEE 029 (B) exposed to $233 \mathrm{~K}$ as air-dried cells for $72 \mathrm{~h}$ and then resuspended in liquid BG-11 medium under routine culture conditions. Ctrl: Control air-dried pellets maintained at RT during the simulation and resuspended in liquid BG-11 medium.

\section{Discussion}

We tested two anhydrobiotic cyanobacteria of the genus Chroococcidiopsis to evaluate their survivability in different icy environments, by using three salt solutions $\left(\mathrm{NaCl}, \mathrm{Na}_{2} \mathrm{SO}_{4}\right.$ and $\left.\mathrm{MgSO}_{4}\right)$ progressively cooled to different sub-freezing temperatures. In each experimental run the cooling time was different due to the cooling temperature gradient of $2 \mathrm{~K} / \mathrm{min}$, however the exposure time at $258 \mathrm{~K}$, $233 \mathrm{~K}$ and $203 \mathrm{~K}$ was the same $(2 \mathrm{~h})$. Viability was assessed by monitoring the capability of entering cell division after transfer to routine growth medium and culture conditions, although the occurrence of viable-non-culturable cells should be taken into consideration.

Both strains survived the freezing process at $258 \mathrm{~K}$ and $233 \mathrm{~K}$, but died at $203 \mathrm{~K}$. Moreover, strain CCMEE 171, isolated from the McMurdo Dry Valleys, Antarctica, showed an enhanced survivability compared to strain CCMEE 029, isolated form the Negev Desert, Israel. Indeed, strain CCMEE 171 is psychrotolerant (i.e., capable of metabolizing near $273 \mathrm{~K}$ and with optimal growth temperatures above $288 \mathrm{~K}$ [34]), and its cold-adaptation strategies might account for its enhanced survivability compared to strain CCMEE 029, under the performed icy simulations. Indeed, although adaptations of polar cyanobacteria are doubtless to be deciphered yet, mechanisms such as fatty acid desaturation or enzyme activity at low temperatures [35] might have contributed to its survival. On the other hand, the hot desert strain CCMEE 029, which is resistant to air-drying, showed the capability of facing freezing-induced desiccation.

The survival of both strains after exposure to $258 \mathrm{~K} \mathrm{in} \mathrm{NaCl}$ solution was expected, this temperature being slightly above the eutectic temperature of the $\mathrm{NaCl}-\mathrm{H}_{2} \mathrm{O}$ system $(252.35 \mathrm{~K})$. Therefore, the sample occurred as polycrystalline ice with veins between ice grain boundaries filled with a salty solution with a salt concentration close to $20 \%$ (see Figure 3 in [19]). These conditions probably favored the microbial partitioning within the water-filled veins, since those have a large diameter (i.e. of the order of several $\mu \mathrm{m}$ ) at $258 \mathrm{~K}$ [36]. The partitioning strongly depends on cell size; according to laboratory ice-formation simulations, microbes smaller than $2 \mu \mathrm{m}$ would accommodate inside the veins, while larger ones (about $10 \mu \mathrm{m}$ ) would remain trapped within the ice crystals [12]. As other Pleurocapsalean cyanobacteria, strains CCMEE 171 and CCMEE 029 in addition to binary division that yields about $3 \mu \mathrm{m}$ size single cells and four-cell aggregates, undergo multiple fission that occurs without increasing the mother-cell volume and producing smaller daughter cells [37]. These smaller 
cells could have fit into the liquid veins. However, both strains might have suffered the osmotic stress due to the increased salt concentration occurring in the salt solution filling the veins. In fact, desert cyanobacteria are adapted to face an external environment, namely the atmosphere, while the environment of cells under osmotic stress is an aqueous solution [38]. It is impossible to rule out that, under the simulations, the two cyanobacterial strains performed photosynthesis (if the light reaching the inside of the climatic chamber was enough) or exploited a light-independent energy generation pathway common to cyanobacteria [39] and reported for Chroococcidiopsis cells in deep subsurface rock samples [40]. In either case, their survivability might have been boosted by the exposure to low temperatures. Indeed, when exposed to eutectic $\mathrm{NaCl}$ solution Planococcus halocryophilus died within two weeks at room temperature; however, it survived at $277 \mathrm{~K}$, an increased survival occurring at 258 $\mathrm{K}$ [41]. In addition, the maximum $\mathrm{CaCl}_{2}$ concentration suitable for its growth increased when the temperature was lowered from $298 \mathrm{~K}$ to $277 \mathrm{~K}$ [42].

Both strains CCMEE 171 and CCMEE 029 survived at $258 \mathrm{~K}$ also in $\mathrm{Na}_{2} \mathrm{SO}_{4}$ and $\mathrm{MgSO}_{4}$ salty ices. According to equilibrium chemistry, we should expect that the salty samples would be completely solid, however these results suggest that liquid salty solution could be present inside the icy sample in a supercooled metastable state [43]. Thus, large part of the cells could have partitioned in the vein microenvironment, even though we cannot exclude the entrapment of some of them inside ice crystals. The enhanced survival of strain CCMEE 029 in the presence of $\mathrm{MgSO}_{4}$, compared to CCMEE 171, is puzzling and it may be explained by taking into consideration that under this experimental condition extracellular polymeric substances might have created microscale salinity gradients, which affected the ice crystal growth, in a hitherto unpredictable way, thus increasing its habitability [44].

Even more surprisingly, CCMEE 171 and CCMEE 029 strains survived the exposure to $233 \mathrm{~K}$ in all three salty-ice samples, that is, to a temperature ranging between $20-30 \mathrm{~K}$ below the relevant eutectic temperatures. These results indicate that the metastable state could support the existence of the liquid salt eutectic solution inside the icy sample [43], preserving a favourable microenvironment for bacteria. It should be noticed that at these temperatures the dimension of the veins reduces sensibly, i.e. approximately $1 \mu \mathrm{m}$ at about $223 \mathrm{~K}$ [36]. In any case, we cannot exclude the possibility that cyanobacteria remained entrapped inside the ice crystals, even though so far bacteria have only been detected in veins and nodes [12].

In response to matric water stress, trehalose and sucrose are accumulated in strain CCMEE 029 [45] and strain CCMEE 171 (unpublished). These two non-reducing sugars act as compatible solutes [46] and are required during the initial stages of desiccation [38], although they also stabilize cells upon drying by replacing water molecules and allowing glass formation [47]. Moreover, trehalose not only provides protection during drying, but it is also an excellent cryoprotectant [48]. Indeed, a different accumulation of compatible solutes during freezing-induced desiccation might have accounted for differences in cyanobacterial survival.

In order to successfully vitrify during the exposure in salty ices, cyanobacteria should have accumulated trehalose and sucrose and should have entered the glassy state before intracellular ice formation. It has been reported that during a cooling of $20 \mathrm{~K} / \mathrm{min}$ and in presence of external ice, microbes undergo freeze-induced desiccation and glass transition at temperatures between $263 \mathrm{~K}$ and $247 \mathrm{~K}$ [17]. In the present simulations, $2 \mathrm{~K} / \mathrm{min}$ cooling rate was used: hence, the intracellular ice formation was probably avoided, and cells were probably dried before reaching the nucleation temperature [49].

Both strains CCMEE 171 and CCMEE 029 died at $203 \mathrm{~K}$ regardless of the salt used. It can be assumed that at this temperature the salt/water binary system is completely solid. Therefore, this value exceeded the survival temperature limit of these cyanobacteria, i.e. the temperature at which a cell enters vitrification but still resumes the metabolism when the temperature limit for metabolism is reached again [17].

Remarkably, air-dried cells of strains CCMEE 171 and CCMEE 029 survived the incubation for 3 days at $193 \mathrm{~K}$ (by using a laboratory refrigerator), as well as $2 \mathrm{~h}$ at $233 \mathrm{~K}$ (by using the climatic chamber). 
Hence, one can speculate that air-drying induced an adaptation different from the osmotic stress response, protecting the cells at subfreezing temperatures. Indeed, dried biofilms of Sphingomonas desiccabilis exposed to brines showed an enhanced resistance compared to hydrated biofilms, suggesting that drying before brining helps protect against brine exposure [50]. On the other hand, both strains CCMEE 171 and CCMEE 029 were killed by the exposure in pure water at $258 \mathrm{~K}, 233 \mathrm{~K}$ and $203 \mathrm{~K}$. This was in line with the observation that freeze-thawing of Planococcus halocryophilus was less lethal in eutectic brines than in salt-free water [42].

In the present work, the endurance of air-dried cells at $193 \mathrm{~K}$ extended the survival temperature threshold of the two investigated cyanobacteria, thus broadening our expectations about the survival limits of life. Actually, as long as an organism can cope with freeze-thawing cycles, there is in principle no minimum low temperature for survival, because being in a frozen state is equivalent to being dormant [51].

Europa's surface has temperatures ranging from $86 \mathrm{~K}$ to $132 \mathrm{~K}$, hence far below the lowest limits known for life on Earth [17]. Nevertheless, the survival reported in this study is significant because it supports a highly speculative, but still intriguing role for vitrification in the context of the potential habitability of icy moons. On Europa, subduction events, due to a plate tectonic-like system, might force an upwards movement of microbial life forms from more favourable niches, such as the ice/water interface or the subsurface ocean, to near-surface temperatures where they would conceivably flash-freeze [52]. Therefore, vitrification might be a strategy for microbial life forms to survive in potentially habitable icy moons such as Europa's icy crust. By entering a dried, frozen state, they could migrate from niches that became non-habitable to new habitable ones, and possibly return to metabolic activity.

Author Contributions: Conceptualization, B.C., A.B., E.P. and D.B.; Methodology, B.C., A.C., C.F., E.M., S.E.L. and F.D.P.; Supervision, A.B., E.P. and D.B.; Writing—original draft, D.B.; Writing—review \& editing, B.C., A.B. and E.P.

Funding: This research was supported by the Italian Space Agency (ASI, DC-VUM-2017-034, Grant $n^{\circ}$ 2019-3 U.O Life in Space) and by ASI/INAF Agreement $n^{\circ}$ 2013-056-R.O.

Conflicts of Interest: The authors declare no conflict of interest.

\section{References}

1. Cockell, C.S.; Bush, T.; Bryce, C.; Direito, S.; Fox-Powell, M.; Harrison, J.P.; Lammer, H.; Landenmark, H.; Martin-Torres, J.; Nicholson, N.; et al. Habitability: A review. Astrobiology 2016, 16, 89-117. [CrossRef] [PubMed]

2. Chyba, C.F.; Phillips, C.B. Europa as an abode of life. Orig. Life Evol. Biosph. 2002, 32, 47-68. [CrossRef] [PubMed]

3. Waite, J.H.; Glein, C.R.; Perryman, R.S.; Teolis, B.D.; Magee, B.A.; Miller, G.; Grimes, J.; Perry, M.E.; Miller, K.E.; Bouquet, A.; et al. Cassini finds molecular hydrogen in the Enceladus plume: Evidence for hydrothermal processes. Science 2017, 356, 155-159. [CrossRef] [PubMed]

4. Lowell, R.P.; DuBose, M. Hydrothermal systems on Europa. Geophys. Res. Lett. 2005, 32, L05202. [CrossRef]

5. Deamer, D.; Damer, B. Can life begin on Enceladus? A perspective from hydrothermal chemistry. Astrobiology 2017, 17, 834-839. [CrossRef]

6. Roth, L.; Saur, J.; Retherford, K.D.; Strobel, D.F.; Feldman, P.D.; McGrath, M.A.; Nimmo, F. Transient water vapor at Europa's south pole. Science 2014, 343, 171-174. [CrossRef]

7. Pappalardo, R.T.; Head, J.W.; Greeley, R.; Sullivan, R.J.; Pilcher, C.; Schubert, G.; Moore, W.B.; Carr, M.H.; Moore, J.M.; Belton, M.J.; et al. Geological evidence for solid-state convection in Europa's ice shell. Nature 1998, 391, 365-368. [CrossRef]

8. Laughlin, G.; Adams, F.C. The frozen Earth: Binary scattering events and the fate of the solar system. Icarus 2000, 145, 614-627. [CrossRef]

9. Abbot, D.S.; Switzer, E.R. The Steppenwolf: A proposal for a habitable planet in interstellar space. Astrophys. J. Lett. 2011, 735, L27. [CrossRef] 
10. Lingam, M.; Loeb, A. Subsurface exolife. Int. J. Astrobiol. 2019, 18, 112-141. [CrossRef]

11. Garcia-Lopez, E.; Cid, C. Glaciers and ice sheets as analog environments of potentially habitable icy worlds. Front. Microbiol. 2017, 8, 1407. [CrossRef] [PubMed]

12. Mader, H.M.; Pettitt, M.E.; Wadham, J.L.; Wolff, E.W.; Parkes, R.J. Subsurface ice as a microbial habitat. Geology 2006, 34, 169-172. [CrossRef]

13. Price, P.B. A habitat for psychrophiles in deep Antarctic ice. Proc. Natl. Acad. Sci. USA 2000, 97, $1247-1251$. [CrossRef] [PubMed]

14. Tung, H.C.; Price, P.B.; Bramall, N.E.; Vrdoljak, G. Microorganisms metabolizing on clay grains in 3-km-deep Greenland basal ice. Astrobiology 2006, 6, 69-86. [CrossRef] [PubMed]

15. Rohde, R.A.; Price, P.B. Diffusion-controlled metabolism for long-term survival of single isolated microorganisms trapped within ice crystals. Proc. Natl. Acad. Sci. USA 2007, 104, 16592-16597. [CrossRef]

16. Boetius, A.; Anesio, A.M.; Deming, J.W.; Mikucki, J.A.; Rapp, J.Z. Microbial ecology of the cryosphere: Sea ice and glacial habitats. Nat. Rev. Microbiol. 2015, 13, 677-690. [CrossRef]

17. Clarke, A.; Morris, G.J.; Fonseca, F.; Murray, B.J.; Acton, E.; Price, H.C. A low temperature limit for life on Earth. PLoS ONE 2013, 8, e66207. [CrossRef]

18. Price, P.B.; Sowers, T. Temperature dependence of metabolic rates for microbial growth, maintenance, and survival. Proc. Natl. Acad. Sci. USA 2004, 101, 4631-4636. [CrossRef]

19. McCarthy, C.; Cooper, R.F.; Kirby, S.H.; Rieck, K.D.; Stern, L.A. Solidification and microstructures of binary ice-I/hydrate eutectic aggregates. Am. Mineral. 2007, 92, 1550-1560. [CrossRef]

20. Barletta, R.E.; Priscu, J.C.; Mader, H.M.; Jones, W.L.; Roe, C.H. Chemical analysis of ice vein microenvironments: II. Analysis of glacial samples from Greenland and Antarctica. J. Glaciol. 2012, 58, 1109-1118. [CrossRef]

21. Dalton, J.B.; Shirley, J.H.; Prockter, L.M. Surface geology of Europa: A window to subsurface composition and habitability. Geophys. Res. Abstr. 2010, 12, 2270-2271.

22. Hand, K.P.; Carlson, R.W. Europa's surface color suggests an ocean rich with sodium chloride. Geophys. Res. Lett. 2015, 42, 3174-3178. [CrossRef]

23. Dickson, J.L.; Head, J.W.; Levy, J.S.; Marchant, D.R. Don Juan Pond, Antarctica: Near-surface $\mathrm{CaCl}_{2}-\mathrm{Brine}$ feeding Earth's most saline lake and implications for Mars. Sci. Rep. 2013, 3, 1166. [CrossRef] [PubMed]

24. Pontefract, A.; Zhu, T.F.; Walker, V.K.; Hepburn, H.; Lui, C.; Zuber, M.T.; Ruvkun, G.; Carr, C.E. Microbial diversity in a hypersaline sulfate lake: A terrestrial analog of ancient Mars. Front. Microbiol. 2017, 8, 1819. [CrossRef]

25. Sharma, A.; Scott, J.H.; Cody, G.D.; Fogel, M.L.; Hazen, R.M.; Hemley, R.J.; Huntress, W.T. Microbial activity at gigapascal pressures. Science 2002, 295, 1514-1516. [CrossRef]

26. Billi, D. Anhydrobiotic Rock-Inhabiting Cyanobacteria: Potential for astrobiology and biotechnology. In Adaptation of Microbial Life to Environmental Extremes: Novel Research Results and Application; Stan-Lotter, H., Fendrihan, F., Eds.; Springer: Vienna, Austria, 2012; pp. 119-132.

27. Billi, D.; Baqué, M.; Verseux, C.; Rothschild, L.J.; de Vera, J.-P. Desert cyanobacteria-Potential for space and Earth applications. In Adaption of Microbial Life to Environmental Extremes, 2nd ed.; Stan-Lotter, H., Fendrihan, F., Eds.; Springer International Publishing: New York, NY, USA, 2017; pp. 133-146.

28. Goordial, J.; Davila, A.; Lacelle, D.; Pollard, W.; Marinova, M.M.; Greer, C.W.; DiRuggiero, J.; McKay, C.P.; Whyte, L.G. Nearing the cold-arid limits of microbial life in permafrost of an upper dry valley, Antarctica. ISME J. 2016, 10, 1613-1624. [CrossRef]

29. Friedmann, E.I.; Kappen, L.; Meyer, M.A.; Nienow, J.A. Long-term productivity in the cryptoendolithic communities of the Ross desert, Antarctica. Microb. Ecol. 1992, 25, 51-69. [CrossRef]

30. Baqué, M.; de Vera, J.P.; Rettberg, P.; Billi, D. The BOSS and BIOMEX space experiments on the EXPOSE-R2 mission: Endurance of the desert cyanobacterium Chroococcidiopsis under simulated space vacuum, Martian atmosphere, UVC radiation and temperature extremes. Acta Astronaut. 2013, 91, 180-186. [CrossRef]

31. Ocampo-Friedmann, R.; Meyer, M.A.; Chen, M.; Friedmann, E.I. Temperature response of Antarctic cryptoendolithic photosynthetic microorganisms. Polarforschung 1988, 58, 121-124.

32. Rippka, R.; Deruelles, J.; Waterbury, J.B.; Herdman, M.; Stanier, R.Y. Generic assignments, strain histories and properties of pure cultures of cyanobacteria. J. Gen. Microbiol. 1979, 111, 1-61. [CrossRef]

33. Billi, D. Desert cyanobacteria under space and planetary simulations: A tool for searching for life beyond Earth and supporting human space exploration. Int. J. Astrobiol. 2018, 18, 483-489. [CrossRef] 
34. Singh, S.M.; Elster, J. Cyanobacteria in Antarctic Lake Environments. In Algae and Cyanobacteria in Extreme Environments. Cellular Origin, Life in Extreme Habitats and Astrobiology; Seckbach, J., Ed.; Springer: Dordrecht, The Netherlands, 2007; pp. 303-320.

35. Chrismas, N.A.M.; Anesio, A.M.; Sánchez-Baracaldo, P. The future of genomics in polar and alpine cyanobacteria. FEMS Microbiol. Ecol. 2018, 94(4), fiy032. [CrossRef] [PubMed]

36. Price, P.B. Microbial life in glacial ice and implications for a cold origin of life. FEMS Microbiol. Ecol. 2007, 59, 217-231. [CrossRef] [PubMed]

37. Rippka, R.; Waterbury, J.B.; Herdman, M.; Castenholz, R.W. The Cyanobacteria: Subsection 2 (formerly Pleurocapsales Geitler 1925, emend. Waterbury and Stanier 1978). In Bergeys Manual of Systematic Bacteriology; Boone, D.R., Castenholz, R.W., Eds.; Springer-Verlag: New York, NY, USA, 2001; pp. 1746-1770.

38. Billi, D.; Potts, M. Life and death of dried prokaryotes. Res. Microbiol. 2002, 153, 7-12. [CrossRef]

39. Stal, L.J.; Moezelaar, R. Fermentation in cyanobacteria. FEMS Microbiol. Rev. 1997, 21, 179-211. [CrossRef]

40. Puente-Sánchez, F.; Arce-Rodríguez, A.; Oggerin, M.; García-Villadangos, M.; Moreno-Paz, M.; Blanco, Y.; Rodríguez, N.; Bird, L.; Lincoln, S.A.; Tornos, F.; et al. Viable cyanobacteria in the deep continental subsurface. PNAS USA 2018, 115, 10702-10707. [CrossRef]

41. Heinz, J.; Schirmack, J.; Airo, A.; Kounaves, S.P.; Schulze-Makuch, D. Enhanced microbial survivability in subzero brines. Astrobiology 2018, 18, 1171-1180. [CrossRef]

42. Heinz, J.; Waajen, A.C.; Airo, A.; Alibrandi, A.; Schirmack, J.; Schulze-Makuch, D. Bacterial growth in chloride and perchlorate brines: Halotolerances and salt stress responses of Planococcus halocryophilus. Astrobiology 2019, 19, 1377-1387. [CrossRef]

43. Toner, J.D.; Catling, D.C.; Light, B. Soluble salts at the Phoenix Lander site, Mars: A reanalysis of the wet chemistry laboratory data. Geochim. Cosmochim Acta 2014, 136, 142-168. [CrossRef]

44. Ewert, M.; Deming, J.W. Sea ice microorganisms: Environmental constraints and extracellular responses. Biology 2013, 2, 603-628. [CrossRef]

45. Hershkovitz, N.; Oren, A.; Cohen, Y. Accumulation of trehalose and sucrose in cyanobacteria exposed to matric water stress. Appl. Environ. Microbiol. 1991, 57, 645-648. [PubMed]

46. Klähn, S.; Hagemann, M. Compatible solute biosynthesis in cyanobacteria. Environ. Microbiol. 2011, 13, 551-562. [CrossRef] [PubMed]

47. Crowe, J.H.; Carpenter, J.F.; Crowe, L.M. The role of vitrification in anhydrobiosis. Annu. Rev. Physiol. 1998, 60, 73-103. [CrossRef] [PubMed]

48. Carpenter, J.F.; Prestrelski, S.J.; Arakawa, T. Separation of freezing- and drying-induced denaturation of lyophilized proteins using stress-specific stabilization. I. Enzyme activity and calorimetric studies. Arch. Biochem. Biophys. 1993, 303, 456-464. [CrossRef] [PubMed]

49. Seki, S.; Kleinhans, F.W.; Mazur, P. Intracellular ice formation in yeast cells vs. cooling rate: Predictions from modeling vs. experimental observations by differential scanning calorimetry. Cryobiology 2008, 58, 157-165. [CrossRef] [PubMed]

50. Stevens, A.H.; Childers, D.; Fox-Powell, M.; Nicholson, N.; Jhoti, E.; Cockell, C.S. Growth, viability, and death of planktonic and biofilm Sphingomonas desiccabilis in simulated Martian brines. Astrobiology 2019, 19, 87-98. [CrossRef]

51. Schulze-Makuch, D.; Airo, A.; Schirmack, J. The Adaptability of Life on Earth and the Diversity of Planetary Habitats. Front. Microbiol. 2017, 8, 2011. [CrossRef]

52. Martin, A.; McMinn, A. Sea ice, extremophiles and life on extra-terrestrial ocean worlds. Int. J. Astrobiol. 2017, 17, 1-16. [CrossRef]

(C) 2019 by the authors. Licensee MDPI, Basel, Switzerland. This article is an open access article distributed under the terms and conditions of the Creative Commons Attribution (CC BY) license (http://creativecommons.org/licenses/by/4.0/). 